\title{
Mitogenic activity of high molecular weight forms of insulin-like growth factor-II in amniotic fluid
}

\author{
J Blahovec ${ }^{1}$, Z Kostecka ${ }^{1}$, M-C Lacroix ${ }^{2}$, L Cabanié ${ }^{3}$, F Godeau, \\ J Mester ${ }^{4}$ and $F$ Cavaillé \\ INSERM U 515, Hôpital St-Antoine, 184 rue du Faubourg Saint-Antoine, 75571 Paris cedex 12, France \\ ${ }^{1}$ Department of Chemistry, Biochemistry and Biophysics, University of Veterinary Medicine, Kosice, Slovakia \\ ${ }^{2}$ UREPP, INRA, Jouy-en-Josas, France \\ ${ }^{3}$ UMR 144, CNRS, Institut Curie, Paris, France \\ ${ }^{4}$ INSERM U 482, Hôpital St-Antoine, Paris, France \\ (Requests for offprints should be addressed to F Cavaillé; Email: cavaille@st-antoine.inserm.fr)
}

\begin{abstract}
Amniotic fluid (AF) collected from ewes and goats at mid gestation displayed mitogenic activity in mouse fibroblasts. Upon fractionation of this material by size exclusion chromatography, the mitogenic activity was resolved into two peaks, whose activity was inhibited by an anti-IGF type 1 receptor blocking antibody. One of the peaks contained IGF-I and IGF-II (mature form), whereas the other contained high $M_{\mathrm{r}}$ precursor forms of IGF-II. The presence in this latter fraction of IGF-binding proteins (IGFBP) suggests that the AF IGFBPs do not efficiently inhibit the mitogenic activity of the high $M_{\mathrm{r}}$ forms of
\end{abstract}

IGF-II. In agreement with this conclusion, exogenous IGFBP-1 failed to affect this activity. Analysis of IGF-II in sheep AF showed that the AF concentrations of both forms of IGF-II increased dramatically from mid pregnancy until 106-120 days of gestation, and fell thereafter. The amniotic IGFBPs followed a similar evolution. High $M_{\mathrm{r}}$ forms of IGF-II were also found in human AF, with a pattern of electrophoretic migration different from that of sheep. We suggest that the precursor forms of IGF-II may play an important role in foetal development.

Journal of Endocrinology (2001) 169, 563-572

\section{Introduction}

The importance of amniotic fluid (AF) growth factors for normal foetal growth has been demonstrated in numerous studies. In the sheep, blocking AF ingestion by the foetus results in abnormal development of the gastrointestinal tract and the liver, and inhibits placental growth (Trahair et al. 1986, Avila \& Harding 1991, Trahair \& Harding 1992). By infusing insulin-like growth factor (IGF)-I to the foetus Kimble et al. (1999) were able to restore the disorders induced by ligation of the foetal oesophagus and therefore established the importance of the swallowing of AF growth factors, particularly of the IGFs, in normal foetal development. In the human, epidermal growth factor, transforming growth factor- $\alpha$ and hepatocyte growth factor are present in the $\mathrm{AF}$ and are thought to act in the development of the stomach and the respiratory tract (Kelly et al. 1997, Itakura et al. 1997). Growth factors or hormones present in the AF can be taken up by the foetus not only by AF deglutition, but can also penetrate the lung by inhalation (Haddad et al. 1995), can diffuse through the foetal skin and can be absorbed by the vascularized foetal surface of the placenta (Lind et al.
1972). The presence of IGF-I and IGF-II as well as of several IGF-binding proteins (IGFBPs) in human AF is well documented (Merimee et al. 1984, D'Ercole et al. 1985, Baxter et al. 1987, Busby et al. 1988, Rechler 1993, Chard et al. 1994, Nonoshita et al. 1994, Jones \& Clemmons 1995). There are few studies concerning the IGF system in the AF of the ewe. Wang et al. (1990) found that ewe AF contains an IGFBP of $38 \mathrm{kDa}$ with high affinity for IGF-II and lower concentrations of IGFs than foetal serum.

In this work, we have studied the properties of mitogenic components present in sheep and goat AF at 70 days of pregnancy, the time of the initiation of fast foetal growth in these animals (Ehrhardt \& Bell 1995). Mouse BP-A31 fibroblasts, a cell line well characterized in terms of its response to mitogenic factors (Buchou et al. 1989, Buchou \& Mester 1990, Fagot et al. 1993), were used as indicator cells. After chromatographic fractionation of AF, we have shown two peaks displaying mitogenic activity mediated by the type I IGF receptor. One of these peaks contained IGF-I and IGF-II (mature), whereas the other, eluting in the higher $M_{\mathrm{r}}$ region, contained precursor forms of IGF-II $(17-30 \mathrm{kDa})$. In contrast with the mature form, 
the high $M_{\mathrm{r}}$ forms of IGF-II displayed a mitogenic activity which was not inhibited by AF IGFBPs or by exogenous IGFBP-1.

\section{Materials and Methods}

\section{Reagents}

Insulin was from Novo (Copenhagen, Denmark). Recombinant human IGF-I and IGF-II were a gift from CibaGeigy/Novartis (Basel, Switzerland). IGFBP-1 purified from human AF was kindly provided by Dr J W van Neck (Professor Drop's laboratory, Erasmus University, Rotterdam, The Netherlands). Recombinant human IGFBP-3 was a gift from Celtrix Pharmaceuticals (Santa Clara, CA, USA). The anti-IGF-I and anti-IGF-II antibodies were from Upstate Biotechnology (Euromedex, Souffelweyersheim, France). The monoclonal anti-IGF type 1 receptor blocking antibody (clone $\alpha$ IR 3 ) was from Oncogene (France Biochem, Meudon, France). Methyl${ }^{3} \mathrm{H}$-thymidine was from Amersham (Les Ulis, France). All other compounds (reagent grade) were from regular commercial sources.

\section{Amniotic fluid}

AF was collected by puncture of the amniotic sac of ewes or goats which were previously killed or anaesthetized in accordance with the rules of the European Convention (86/609/EEC), Slovak legislation and French recommendations for the use of experimental animals (guideline 04/19/1988). A single AF sample was collected per animal at different times of the pregnancy (from 41 days to term). Throughout this work, AF from sheep and goats were used and gave similar results. Human AF samples were collected for prenatal diagnosis purposes at the Service of Obstetrics and Gynaecology of Saint-Antoine University Hospital, according to French legislation and ethical rules. Aliquots of AF from 15 women (16-18 weeks of gestation) were supplied for this study by the cytogenetics laboratory of the hospital.

Aliquots of $\mathrm{AF}$ were maintained at $-20{ }^{\circ} \mathrm{C}$. AF samples from individual subjects were analysed, except for peptide fractionation. In this case, sheep or goat AF samples collected at 70 days of pregnancy were pooled $(250 \mathrm{ml})$ and delipidated by chloroform (Blahovec et al. 1997).

\section{Peptide fractionation}

Delipidated AF was concentrated at $37^{\circ} \mathrm{C}$ by rotary evaporator and submitted to gel filtration on a Sephadex G-10 column (Amersham Pharmacia, Saclay, France) equilibrated in $0.04 \mathrm{M} \mathrm{NH}_{4} \mathrm{HCO}_{3}$. Void volume fraction (fraction $\mathrm{A} ; M_{\mathrm{r}} \geqslant 700$ ) and total volume of the column (fraction B) were collected and lyophilized. Peptide content of the fractions was measured by the ninhydrin reaction.

Peptides (100-150 mg) eluted in fraction A were dissolved in $10 \%$ acetic acid $(15-20 \mathrm{ml})$ and loaded onto a Sephadex G-50 column $(30 \times 900 \mathrm{~mm}$; Amersham Pharmacia). Elution was carried out in the same medium at a flow rate of $9.5 \mathrm{ml} / \mathrm{h}$, and monitored by optical density at $280 \mathrm{~nm}$. The position of elution of ${ }^{125}$ I-IGF-I as well as the void volume (elution of Blue dextran) and the total volume (elution of potassium chromate) were established under the same conditions. The fractions obtained were lyophilized and reconstituted with $0.5 \mathrm{ml} \mathrm{H}_{2} \mathrm{O}$ for further analysis.

For further purification, G-50 column fractions of interest were pooled and loaded on a Sepharose 4B lentil lectin column (Amersham Pharmacia) to eliminate $\mathrm{N}$-glycosylated components. The flow-through fraction was then loaded on an anion exchange column (Mono Q mini column, $0.1 \mathrm{ml}$; Amersham Pharmacia) equilibrated with $30 \mathrm{mM}$ Tris-HCl, $\mathrm{pH} 8 \cdot 0$. Elution was performed with a linear $\mathrm{NaCl}$ gradient $(0-0 \cdot 2 \mathrm{M})$.

\section{Proliferation tests}

Mouse BP-A31 fibroblasts were maintained in minimal essential medium modification $\alpha$ (MEM $\alpha$ ) supplemented with $6 \%$ foetal bovine serum (FBS) in a humidified air $/ \mathrm{CO}_{2}(5 \%)$ atmosphere. For the detection of mitogenic activity, $20 \times 10^{3}$ cells were seeded per well in 24-well boxes. After $24 \mathrm{~h}$, the medium was replaced with $1 \mathrm{ml}$ MEM $\alpha$ plus $2 \cdot 5 \mu \mathrm{M} \mathrm{FeSO}_{4}$ and the cells were allowed to enter quiescence for an additional $24 \mathrm{~h} .{ }^{3} \mathrm{H}$-Thymidine $(2 \mu \mathrm{Ci})$ was added to the wells, together with substances and/or column fractions to be tested. After $24 \mathrm{~h}$, the incorporation was terminated by acidification with $1 \mathrm{M}$ ascorbic acid ( 3 drops $/ \mathrm{ml}$ ). The cells were fixed and washed with $5 \%$ trichloroacetic acid and solubilized in $0 \cdot 1 \mathrm{M} \mathrm{NaOH}$ for counting in a liquid scintillation spectrometer.

Forskolin $\left(10^{-5} \mathrm{M}\right)$ and phorbol myristate acetate (PMA; $100 \mathrm{ng} / \mathrm{ml}$ ) were used to investigate the role of protein kinase A and protein kinase $\mathrm{C}$ (PKC) signalling pathways.

The presence and mitogenic activity of components of the IGF system in chromatographic fractions of AF were investigated by using IGF-I (1 nM), IGF-II $(10 \mathrm{nM})$, anti-IGF-I $(10 \mu \mathrm{g} / \mathrm{ml})$ or anti-IGF-II $(10 \mu \mathrm{g} / \mathrm{ml})$ antibodies, neutralizing anti-IGF type 1 receptor antibody ( $\alpha$ IR 3; $2 \mu \mathrm{g} / \mathrm{ml})$, IGFBP-1 (70 nM) or IGFBP-3 (10 nM).

\section{Western immunoblot and ligand blot}

Analysis of IGF-II by Western immunoblot was performed with a specific anti-IGF-II antibody $(1 \mu \mathrm{g} / \mathrm{ml})$ directed against rat IGF-II, after electrophoresis under reducing 
conditions in 15\% polyacrylamide gels (Laemmli 1970) followed by transfer onto nitrocellulose filters (Interchim, Montluçon, France).

IGFBPs were analysed by Western ligand blot as described by Hossenlopp et al. (1990). Aliquots of crude AF or column fractions were adjusted to $1 \%$ sodium dodecyl sulfate (SDS) in non-reducing Laemmli sample buffer and boiled for $5 \mathrm{~min}$. They were fractionated by electrophoresis in 12\% polyacrylamide gel and electroblotted onto nitrocellulose filters. The membrane was then incubated with a mixture of ${ }^{125}$ I-labelled IGF-I and IGF-II (1/1; 500000 c.p.m. per filter). After extensive washing, the filters were exposed with an X-ray sensitive film (Kodak).

\section{Assay of IGFs}

The IGF concentration in Sephadex G-50 column fractions was determined by radioimmunoassay for IGF-I (Bessone et al. 1999) and protein binding assay for IGF-II (Binoux et al. 1986). Before the assays, the column fractions were adjusted to $1 \mathrm{M}$ acetic acid, $0 \cdot 15 \mathrm{M} \mathrm{NaCl}$ and $0.1 \%$ bovine serum albumin. In order to eliminate IGFBPs which would interfere with the assays, the samples were submitted to a filtration on Centricon C 30 (Amicon; Merck Eurolab, Strasbourg, France). Samples were tested in duplicate at two different concentrations. Intra- and interassay coefficients of variation were 4.8 and $10 \%$ respectively for IGF-I and $4 \cdot 8$ and $9 \cdot 5 \%$ for IGF-II. The sensitivities of the assays were $0.85 \mathrm{ng}$ for IGF-I and 0.03 ng for IGF-II.

\section{Results}

Detection and characterization of mitogenic activity

When the delipidated AF was added to serum-deprived BP-A31 cells, there was no effect on ${ }^{3} \mathrm{H}$-thymidine incorporation (data not shown). However, after gel filtration on Sephadex G-10, the fraction eluted in the void volume (fraction A) was able to initiate the cell cycle in serum-deprived BP-A31 cells; in contrast, fraction B, eluted in the total volume of the column, contained small molecules that inhibited the cell cycle (Fig. 1) and were toxic at high concentration.

In order to obtain information concerning the functional characteristics of the growth factor(s) responsible for the observed mitogenic effect of fraction A, we tested the activity of these fractions in the presence of forskolin (activator of adenylyl cyclase) or PMA (activator of PKC) (Fig. 1). Forskolin did not alter the mitogenic activity of fraction A, whereas it abolished the effect of PMA. The activities of fraction $\mathrm{A}$ and PMA were approximately additive. The same results were obtained with two different pools of AF.

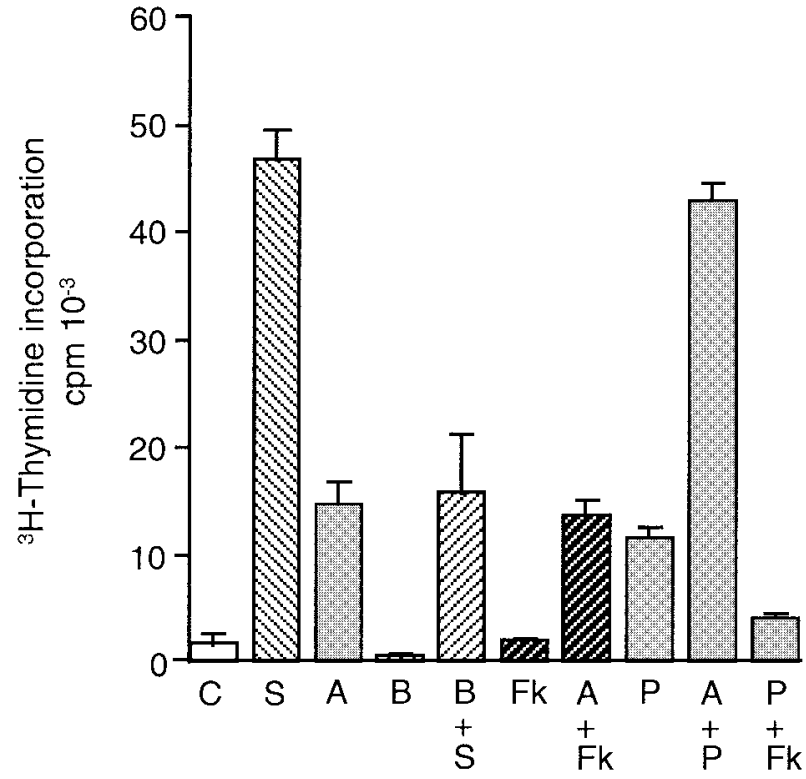

Figure 1 Effect of Sephadex G-10 column fractions on ${ }^{3} \mathrm{H}$ thymidine incorporation by BP-A31 cells. The void volume (fraction A) or total volume (fraction B) of the Sephadex G-10 column were lyophilized and taken up in $10 \%$ acetic acid to a final concentration of $7 \mathrm{mg}$ dry material $/ \mathrm{ml}$. Portions of the fractions were then added to quiescent BP-A31 cells in wells containing $1 \mathrm{ml}$ serum-free MEM $\alpha$ medium; the final concentrations were $25 \mu \mathrm{g} / \mathrm{ml}$. At the same time, the effect of PMA was determined, alone and in combination with fraction A. The inhibition of the mitogenic effects of PMA $(100 \mathrm{ng} / \mathrm{ml})$ and of fraction A by forskolin $\left(10^{-5} \mathrm{M}\right)$ were also assayed. FBS (6\%) was used as positive control, fresh serum-free medium as negative control. ${ }^{3} \mathrm{H}$-Thymidine incorporation was evaluated as described in Materials and Methods. Results are expressed as means \pm S.E.M. of triplicate cultures. The experiment was repeated twice with similar results. $C$, control; $S, F B S$; A, fraction A; B, fraction B; Fk, forskolin; P, PMA.

When fraction A was submitted to size-exclusion chromatography on Sephadex G-50, two peaks of similar mitogenic activity were resolved (Fig. 2). The first peak of activity (peak I; maximum in fractions 20 and 21) eluted immediately after the void volume of the column, while the second one coincided with the position of elution of ${ }^{125}$ I-IGF-I (peak II; maximum in fractions 27 and 28). This pattern was reproducible in four experiments using different AF pools from sheep or goats.

IGF-I and IGF-II were assayed respectively by immuno- and binding assay in mitogenically active Sephadex G-50 fractions, after a filtration which eliminated proteins of $M_{\mathrm{r}}>10 \mathrm{kDa}$, as described in Materials and Methods. IGF-I as well as IGF-II were detected in peak II, with a maximum in fractions 27 and 28, at the position of elution of $\mathrm{I}^{125}$-IGF-I (Fig. 3b). The concentrations of IGF-II were much higher than those of IGF-I (maximal concentrations of 123.2 and $9 \cdot 6 \mathrm{ng} / \mathrm{ml}$ respectively). Small amounts of IGFs were also present in peak I fractions. Western immunoblot analysis of the Sephadex 


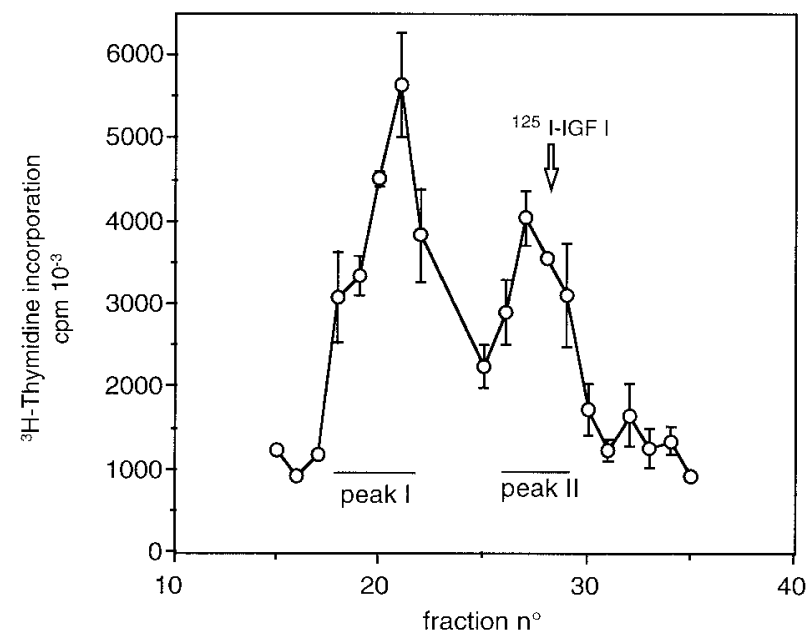

Figure 2 Mitogenic activity present in fraction A was separated into two components by Sephadex G-50 gel filtration. Fraction A of the Sephadex G-10 column was further fractionated on Sephadex G-50. The fractions were lyophilized and reconstituted with $0.5 \mathrm{ml} \mathrm{H}_{2} \mathrm{O}$. Twenty microlitres of the solubilized fractions were added to quiescent BP-A31 cells in serum-free MEM $\alpha$ medium and ${ }^{3} \mathrm{H}$-thymidine incorporation was measured over $24 \mathrm{~h}$. The position of ${ }^{125}$ I-IGF-I elution is indicated. Data are means \pm S.E.M. of triplicate cultures. The same profile of elution was obtained with four different AF preparations.

G-50 fractions with a specific anti-IGF-II antibody (Duguay et al. 1998) showed, however, that IGF-II immunoreactive material was present in large amounts both in peak I and II (Fig. 3a). The IGF-II immunoreactive peptides observed in peak I differed from those in peak II by their $M_{\mathrm{r}}$ values. Fractions 26-29 of peak II contained an IGF-II signal which migrated at the same position as recombinant IGF-II $(6 \mathrm{kDa})$, the intensity of the signal varying in parallel to the concentrations of IGF-II determined by binding assay (Fig. 3b). Fractions 18-27 of peak I contained IGF-II immunoreactive peptides which migrated with a higher apparent $M_{\mathrm{r}}$ $(17-30 \mathrm{kDa})$, with a maximum in fractions 20-24 (Fig. 3a). IGF-II found by binding assay in fractions 18-24 corresponds to the mature (low $M_{\mathrm{r}}$ ) form present at amounts too low for detection by Western blotting (note that large $M_{\mathrm{r}}$ precursor forms are eliminated together with IGFBPs by Centricon filtration). The concentrations of IGF-I estimated by immunoassay in Sephadex G-50 fractions were also too low to be detected by immunoblotting (data not shown).

Two IGFBP bands were detected by Western ligand blotting with ${ }^{125}$ I-labelled IGFs in Sephadex G-50 fractions 18-22 (Fig. 3c). These IGFBPs migrated respectively as human IGFBP-3 (39-45 kDa) and IGFBP-1 (29 kDa). Attempts to reveal goat and sheep IGFBPs by immunoblotting using polyclonal antibodies raised against human IGFBP-1 and IGFBP-3 were unsuccessful, probably due to the absence of cross-reactivity with ruminant proteins.
The activies of the pooled fractions of peak I or II of Sephadex G-50 column were both strongly inhibited by the $\alpha$ IR 3 antibody (Fig. 4a) which blocks the IGF type 1 receptor (Kull et al. 1983, Rohlik et al. 1987). The anti-IGF-I antibody, in conditions in which it inhibited $1 \mathrm{nM}$ IGF-I by approximately $80 \%$, strongly inhibited peak II in which both IGF-I and IGF-II were detected by radioimmunoassay (74\% inhibition), but had no effect on peak I activity. IGF-I is a more potent mitogen than IGF-II in BP-A31 cells; $10 \mathrm{nM}$ IGF-II was required to produce an effect similar to $1 \mathrm{nM}$ IGF-I (Fig. $4 \mathrm{~b}$ ).

As peak I contained IGFBPs (Fig. 3c) together with large amounts of high $M_{\mathrm{r}}$ forms of IGF-II, we investigated the effects of IGFBP-1 and IGFBP-3 in the BP-A31 cells and their inhibition of the mitogenic effect of recombinant IGF-II. No IGFBPs were detected by Western ligand blotting in the supernatant of quiescent BP-A31 cells (Fig. 3c). Recombinant IGF-II (10 $\mathrm{nM})$ produced a large increase in ${ }^{3} \mathrm{H}$-thymidine incorporation (500\%) compared with control. IGFBP-3 alone at $10 \mathrm{nM}$ was not mitogenic in these cells (Fig. 5). IGFBP-3 present during the $24 \mathrm{~h}$ before IGF-II had a very low inhibitory effect on IGF-II mitogenic activity, and displayed a weak inhibitory effect when added together with IGF-II (Fig. 5). Purified human AF IGFBP-1 at $70 \mathrm{nM}$ efficiently inhibited the mitogenic activity of $1 \mathrm{nM}$ IGF-I, and reduced the effect of $10 \mathrm{nM}$ IGF-II by 45\% (Fig. 4b); when added together with fractions of peak I or II, IGFBP-1 produced only a weak inhibition of the ${ }^{3} \mathrm{H}$-thymidine incorporation induced by peak I, while the activity of peak II was reduced by approximately $60 \%$ (Fig. 4 b).

In order to further characterize the substances contained in peak I of the Sephadex G-50 column, pooled fractions of peak I were loaded on a lentil lectin column. After passage through the column, the mitogenic activity was found in the flow-through, indicating that it did not carry $\mathrm{N}$-linked sugar residues. When this material was further fractionated on a Mono $\mathrm{Q}$ anion exchange column (Fig. 6a), four peaks absorbing at $280 \mathrm{~nm}$ and $256 \mathrm{~nm}$ were detected. Two of these peaks (fractions 10-12 and 13-15) were endowed with mitogenic activity (Fig. 6b). Analysis of these fractions by Western immunoblot with an anti-IGF-II antibody revealed a band at approximately $19 \mathrm{kDa}$ in fraction 11 , while fraction 14 contained IGF-II-immunoreactive proteins with $M_{\mathrm{r}}$ ranging from 17 to $30 \mathrm{kDa}$, similar to those found in the initial material (Fig. 6c). There was no IGF-II signal in fractions devoid of mitogenic activity (Fig. 6b and c).

\section{Analysis of IGF-II and IGFBPs in sheep AF in the course of gestation}

When crude sheep AF was submitted to Western immunoblot analysis with an anti-IGF-II antibody (Fig. 7a), a band migrating as recombinant IGF-II $(6 \mathrm{kDa})$ was found at all stages of gestation investigated 
a)

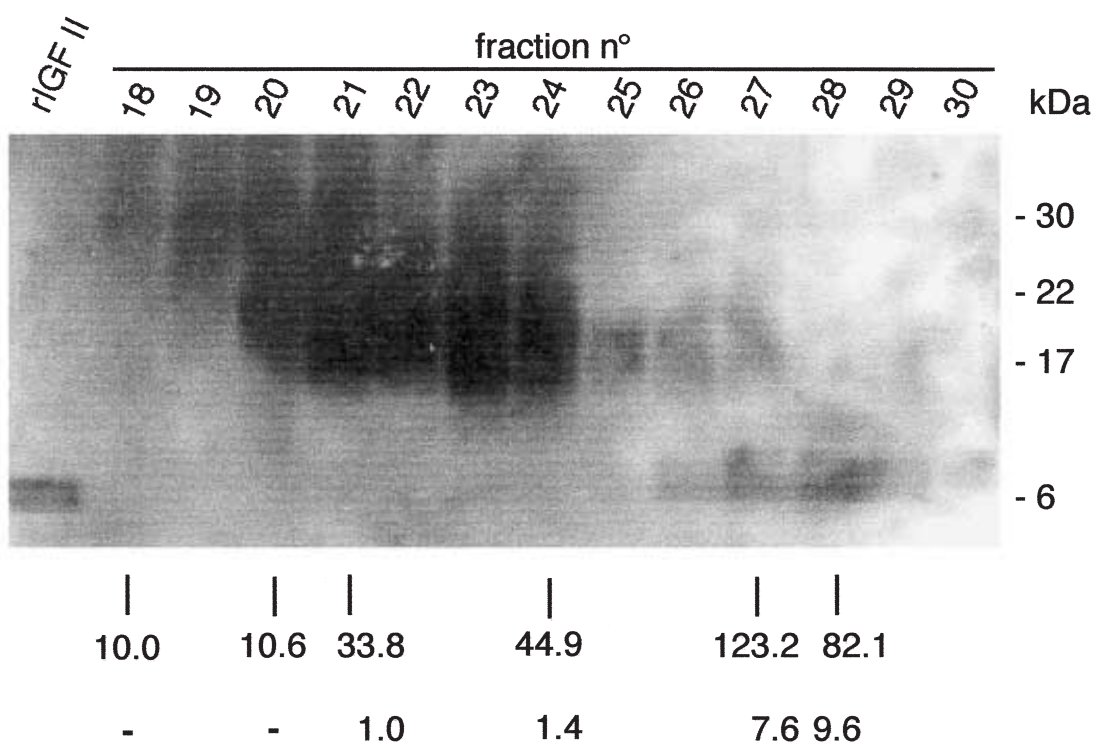

c)

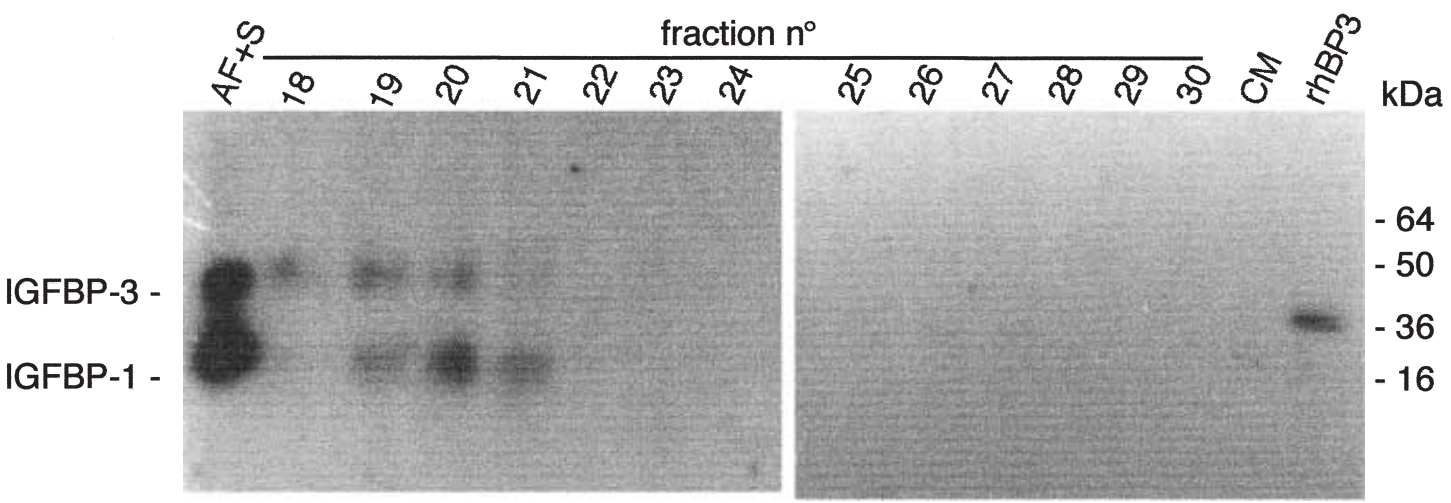

Figure 3 Presence of IGFs and IGFBPs in Sephadex G-50 fractions. (a) Western immunoblotting. One hundred microlitres of the indicated fractions were brought to dryness under vacuum, reconstituted with $50 \mu \mathrm{l}$ of reducing sample buffer and fractionated by SDS-PAGE (15\% acrylamide), prior to electrotransfer and revelation with anti-IGF-II antibody. Recombinant IGF-II (rIGFII; 5 ng) was loaded in parallel as a control. The position of molecular weight standards is indicated. (b) Radioimmuno- and binding assays. The levels of IGF-I and IGF-II were determined as described in Materials and Methods in the fractions as shown. Minus sign indicates non-detectable level of IGF-I (less than $0.85 \mathrm{ng} / \mathrm{ml}$ ). (c) Western ligand blotting. Ten microlitres of the fractions indicated were loaded in non-reducing sample buffer on $12 \%$ SDS-PAGE and analysed by ligand blotting with ${ }^{125}$ I-IGF-I and ${ }^{125}$ I-IGF-II. Human serum $(2 \mu \mathrm{l})$ and human AF $(2 \mu \mathrm{l})(\mathrm{AF}+\mathrm{S})$, and recombinant human IGFBP-3 (rhBP3; 5 ng) were used as positive controls. CM, conditioned medium of BP-A31 cells $(50 \mu \mathrm{l})$ after $24 \mathrm{~h}$ of serum depletion. The positions of human IGFBP-1 and -3 are indicated. The same result was obtained with two different pools of AF.

(41-140 days). The intensity of this band was low until 75 days, rose therafter to a maximum between 106 and 120 days, and then decreased again. A band migrating at $17 \mathrm{kDa}$ was also recognized by the anti-IGF-II antibody. This signal was variable during early gestation, became strong between 80 and 90 days and reached a maximum between 106 and 120 days. Similarly, human AF (18 weeks of gestation) contained the $6 \mathrm{kDa}$ form of
IGF-II, as well as higher apparent $M_{\mathrm{r}}$ forms of 12 and $15 \mathrm{kDa}$; additional bands of 32 and $37 \mathrm{kDa}$ were also present (Fig. 7a). Fourteen other human AF samples obtained at 16-18 weeks of pregnancy exhibited a similar pattern of IGF-II forms (data not shown).

Sheep AF samples analysed by Western ligand blot (Fig. 7b) contained IGFBPs whose pattern varied with the time of gestation. At the earlier stages, two IGFBPs bands 

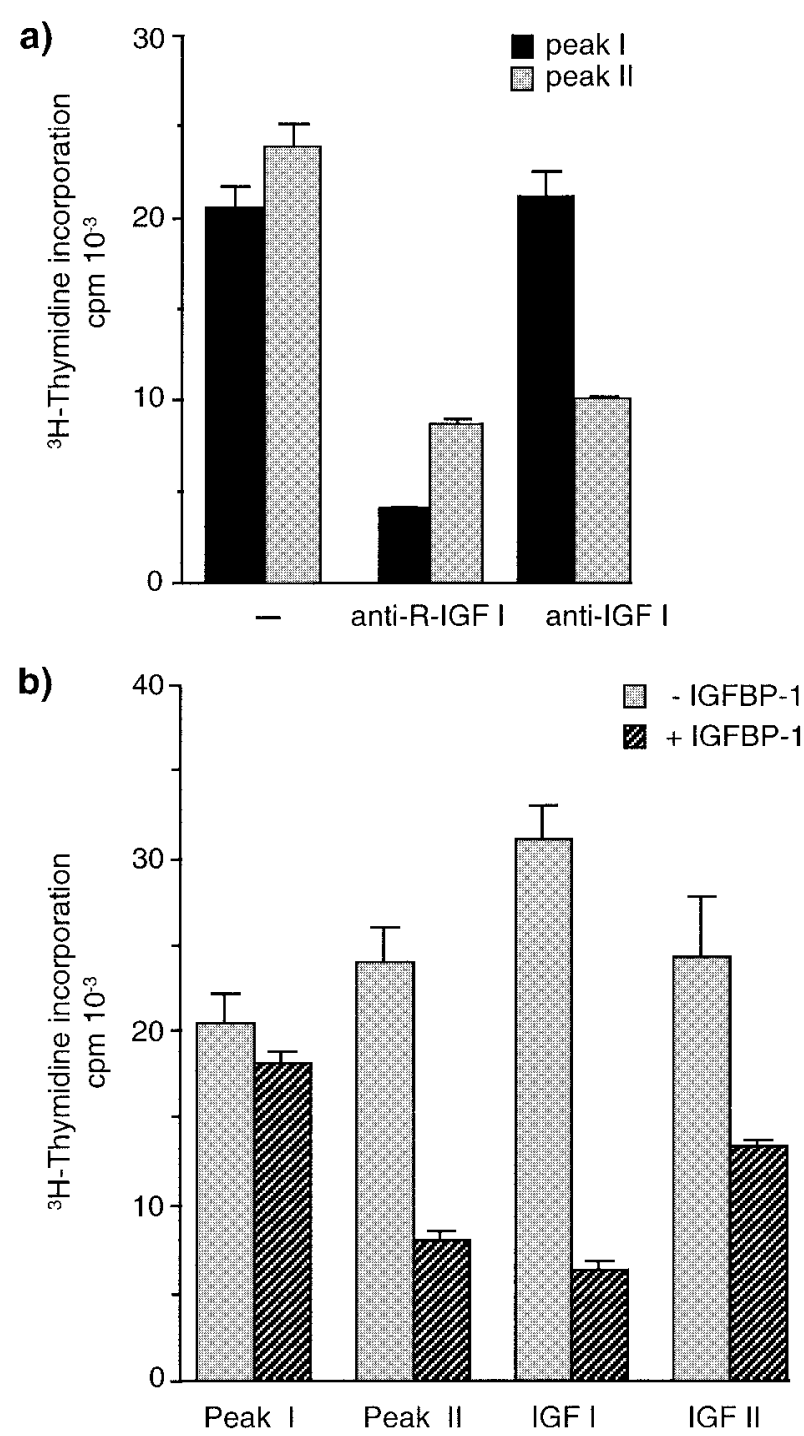

Figure 4 Effects of anti-type 1 IGF receptor, anti-IGF-I and IGFBP-1 on the mitogenic activities of Sephadex G-50 fractions. Incorporation of ${ }^{3} \mathrm{H}$-thymidine in BP-A31 cells over $24 \mathrm{~h}$ was measured after stimulation by $20 \mu \mathrm{l}$ of pooled fractions of peak I or II, as described in Materials and Methods, in the presence or absence of (a) antibodies directed against type 1 IGF receptor (anti-R-IGF I, $\alpha$ IR3, $2 \mu \mathrm{g} / \mathrm{ml}$ ) or IGF-I (anti-IGF-I, $10 \mu \mathrm{g} / \mathrm{ml}$ ) and (b) IGFBP-1 (70 nM). The inhibitory effect of IGFBP-1 on recombinant IGF-I $(1 \mathrm{nM})$ or IGF-II $(10 \mathrm{nM})$ is also shown. Results are expressed as means \pm S.E.M. of triplicate cultures. The experiment was repeated twice with similar results.

migrating at approximately 40 and $45 \mathrm{kDa}$ were shown and two other IGFBPs bands, migrating respectively at approximately 30 and $25 \mathrm{kDa}$, were detectable after day 90. From day 90 onwards, the overall levels of IGFBPs increased dramatically to reach a maximum by day 120 and decreased thereafter.

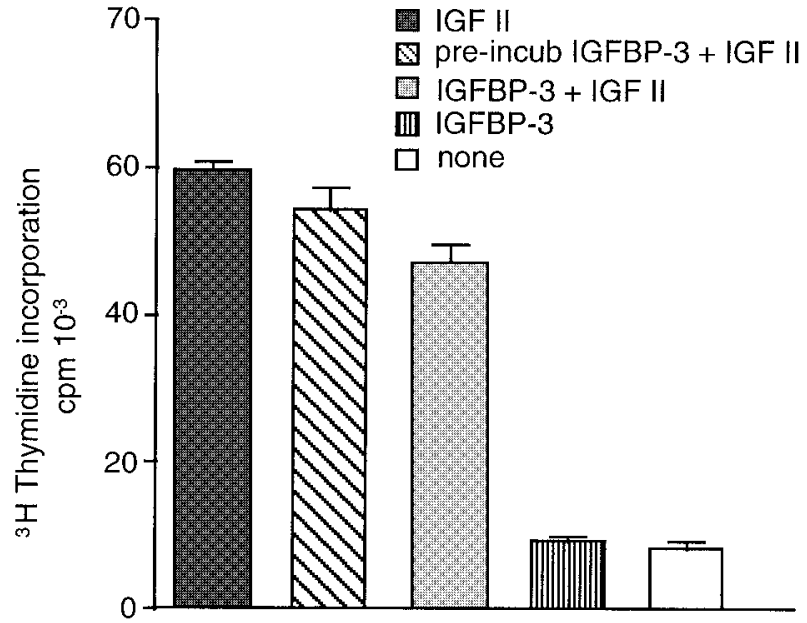

Figure 5 Effects of IGFBP-3 on the mitogenic activity of IGF-II. Quiescent BP-A31 cells were incubated for $24 \mathrm{~h}$ with IGF-II (10 nM), IGFBP-3 (10 nM) or IGF-II+IGFBP-3, in the presence of ${ }^{3} \mathrm{H}$-thymidine. Where indicated, IGFBP-3 was present during the $24 \mathrm{~h}$ prior to the addition of ${ }^{3} \mathrm{H}$-thymidine (pre-incub). The ${ }^{3} \mathrm{H}$-thymidine incorporation was determined as described in Materials and Methods. The results shown (means \pm S.E.M. of triplicate cultures) are representative of two experiments.

\section{Discussion}

The AF collected from sheep and goats at 10 weeks of gestation contained mitogenic activity detectable after the removal of inhibitory, low $M_{\mathrm{r}}-$ components. This mitogenic activity displayed the characteristics of IGF. In particular, it was not inhibited by forskolin, inducer of cAMP accumulation which acts as an inhibitor of several other mitogenic agents in the BP-A31 fibroblasts used as indicator cells, such as platelet-derived growth factor and PMA (Buchou et al. 1989), bovine fibroblast growth factor (Buchou \& Mester 1990) and prostaglandin $\mathrm{F}_{2 \alpha}$ (Fagot et al. 1993). Moreover, the effects of the mitogenic component(s) of AF were approximately additive with those of a saturating concentration of PMA $(100 \mathrm{ng} / \mathrm{ml})$, indicating different signal transduction pathways. The mitogenic activity of AF was separated by size exclusion chromatography into two peaks, both inhibited by an anti-type 1 IGF receptor blocking antibody. In agreement with these results, assays of IGF and Western immunoblot confirmed that both IGF-I and IGF-II were present in the fractions with mitogenic activity. Assay of IGFs showed that IGF-I and the $6 \mathrm{kDa}$ mature form of IGF-II were eluted in peak II. On the other hand, peak I contained essentially IGF-II immunoreactive material of high $M_{\mathrm{r}}$ $(17-30 \mathrm{kDa})$ as revealed by Western immunoblotting. The presence of the low $M_{\mathrm{r}}$ mature form of IGF-II in peak II, at the position of elution of ${ }^{125}$ I-IGF-I, was confirmed by Western immunoblotting. The levels of IGF-II and IGF-I indicate that their ratio (12:1) is elevated in sheep $\mathrm{AF}$ at mid gestation, similar to that found at the end of 

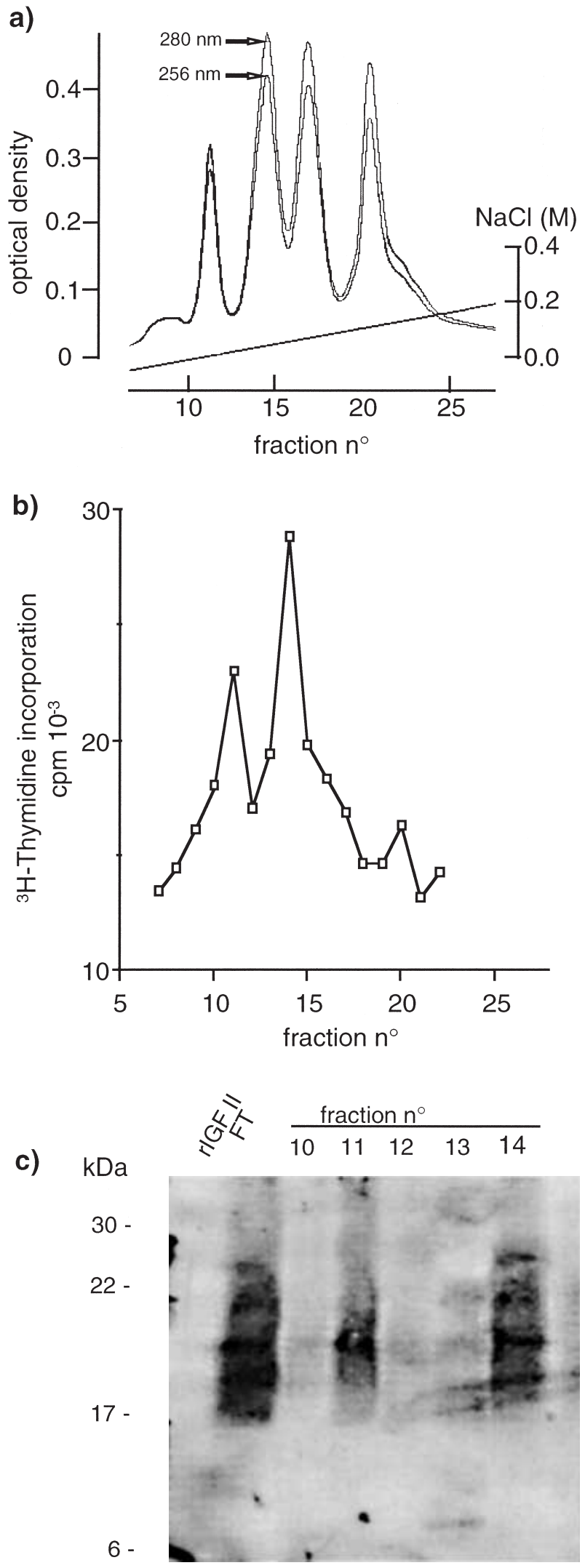

www.endocrinology.org gestation by Wang et al. (1990) and as reported by Merimee et al. (1984) and Nonoshita et al. (1994) in human AF throughout pregnancy.

The Sephadex G-50 peak I of mitogenic activity contained little of the mature IGF-II but instead important amounts of IGF-II immunoreactive peptides of $17-30 \mathrm{kDa}$. After further fractionation by anion exchange chromatography, these high $M_{\mathrm{r}}$ IGF-II immunoreactive proteins were again recovered in the mitogenically active fractions. We concluded that the mitogenic peptides eluted in peak I after chromatography on Sepharose G-50 are high $M_{\mathrm{r}}$ precursor forms of IGF-II. Big IGF-II isoforms were first described by Haselbacher \& Humbel (1982), Daughaday et al. (1988), Shapiro et al. (1990) and Zapf et al. (1992). Jansen et al. (1985) have predicted, according to the cDNA sequence, that IGF-II is synthesized as a precursor, and Hudgins et al. (1992) identified O-glycosylated precursors of IGF-II. High $M_{\mathrm{r}}$ forms of IGF-II are found in several body fluids of healthy individuals. When produced at high levels by certain types of tumours, they induce severe hypoglycaemia (rewieved in Koch et al. 1999). In agreement with our observations, a proIGF-II-immunoreactivity has been detected in human AF (Liu et al. 1993). At least 12 different forms of high $M_{\mathrm{r}}$ IGF-II molecules, with a similar protein backbone of 87 amino acid and different amounts of sialylated, O-linked sugars linked to the E-peptide extension, were identified by Valenzano et al. (1995) and Valenzano et al. (1997) in foetal bovine serum. Other IGF-II isoforms with high $M_{\mathrm{r}}$ are produced by alternative splicing (Jansen et al. 1985) and by processing at Arg 104 (Duguay et al. 1998). In our study, we have shown that ewe AF contains at least three high $M_{\mathrm{r}}$ forms of IGF-II and that human AF also contains high $M_{\mathrm{r}}$ IGF-II forms, with a different pattern of migration in SDS-PAGE, suggesting that the process of maturation of IGF-II differs between ruminants and humans. These results indicate that, in both species, the high $M_{\mathrm{r}}$ precuror forms of IGF-II are secreted into the AF. It is necessary to take this result into account to measure IGF-II concentrations in AF correctly, as the classical assays evaluate only mature IGF-II. By Western immunoblot, we found that

Figure 6 lon-exchange chromatography of the large $M_{r}$ IGF-II containing Sephadex G-50 fractions. Pooled fractions of peak I from the Sephadex G-50 column were loaded onto Sephrose 4B lentil lectin column. The flow-through (FT; $1.5 \mathrm{ml}$ ) was loaded onto a Mono Q column and eluted with an $\mathrm{NaCl}$ gradient $(0-0 \cdot 2 \mathrm{M})$. Fractions of $75 \mu \mathrm{l}$ were collected. (a) Optical density (at 280 and $256 \mathrm{~nm}$ ) of the fractions eluted from the MonoQ column. (b) Mitogenic activity present in fractions separated on Mono Q column. Five microlitres of each fraction were added to quiescent BP-A31 cells and ${ }^{3} \mathrm{H}$-thymidine incorporation was measured over $24 \mathrm{~h}$. The same profile of elution was observed with two different AF preparations. (c) Western blot analysis. Forty microlitres of lectin column FT and $25 \mu \mathrm{l}$ monoQ fractions were submitted to SDS-PAGE (15\%) under reducing conditions. rIGF II, recombinant IGF-II. The immunoblot was revealed with anti-IGF-II antibody. 
a)

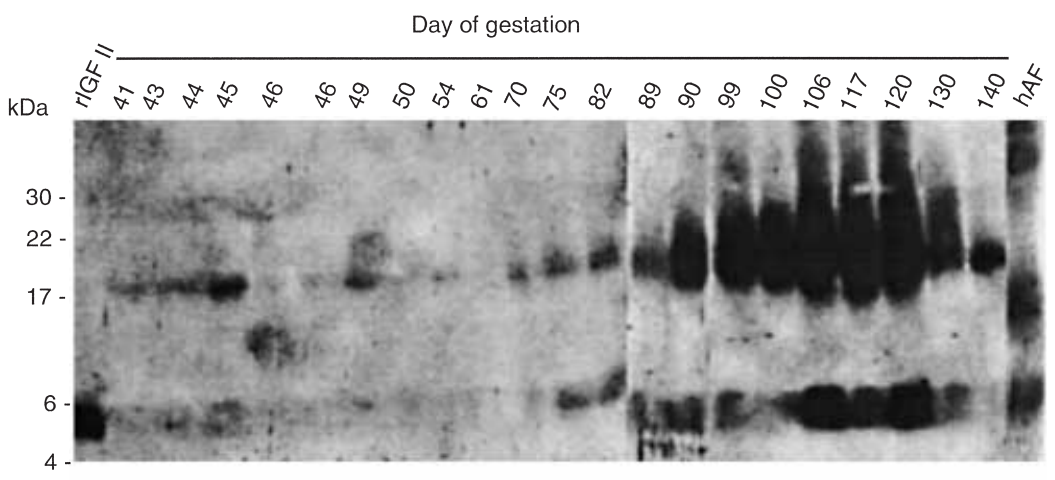

b)

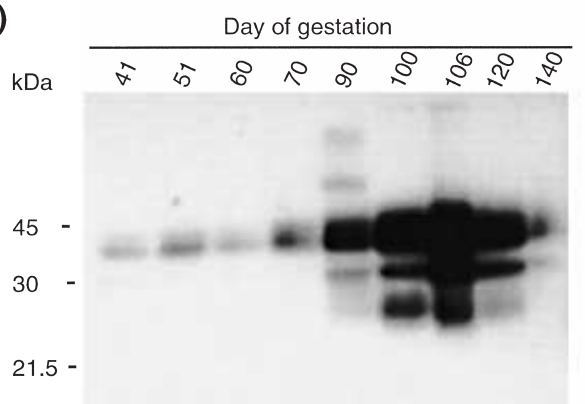

Figure 7 Analysis of IGF-II and IGFBPs in sheep amniotic fluid in the course of gestation. The AF was obtained from different animals by puncture on the days of gestation indicated. (a) Western immunoblot with anti-IGF-II. Samples $(50 \mu \mathrm{l})$ were run on SDS-PAGE $(15 \%)$ in reducing conditions. A human AF sample (18 weeks of pregnancy) was run in parallel (hAF); the same pattern was obtained with 15 different human AF samples at 16-18 weeks of pregnancy (data not shown). Positions of pre-stained molecular weight standards are indicated. (b) Western ligand blot. Samples $(30 \mu \mathrm{l})$ were run on $12 \%$ SDS-PAGE in non-reducing conditions. Ligand blot was performed with ${ }^{125} \mathrm{I}-\mathrm{IGF}-\mathrm{I}$ and $-\mathrm{II}$ as described in Materials and Methods.

AF concentrations of the different forms of IGF-II and of the IGFBPs follow the same pattern of evolution in the course of gestation.

The importance of IGF-II in foetal growth has been confirmed by the inactivation of the IGF-II gene in the mouse (DeChiara et al. 1990). In the sheep, IGF-II mRNA is produced at a high level in the maternal and foetal placenta (Wathes et al. 1998) and foetal plasma is rich in IGF-II, with a concentration at 130 days correlated with foetal weight (Owens et al. 1994). Almost all foetal tissues, particularly the liver, produce IGF-II at higher concentrations than IGF-I (McLellan et al. 1992, Kind et al. 1995). The origin of the IGF-II in sheep AF has not been determined. The increase of IGF-II (mature and precursors forms) in AF occurs after the placental maximal weight has been reached and coincides with the exponential growth of the foetus after 80 days of pregnancy (Ehrhardt \& Bell 1995). It is also to be noted that there is a drop in the IGF-II in AF at the end of gestation as well as a fall in IGF-II mRNAs in foetal tissues and of IGF-II in foetal plasma at term (Mesiano et al. 1989, O'Mahoney et al. 1991, Delhanty \& Han 1993, Forhead et al. 1998, Wathes et al. 1998). The AF IGF-II could originate from the foetus through excretion in the urine. However, after infusion of labelled IGF-II into the femoral vein of the ovine foetus, no movement of IGF-II out of the foetal circulation into foetal fluids was observed (Bassett et al. 1990). The foetal membranes may constitute another potential source of IGF-II, as they are for other components of AF (Wintour et al. 1986).

The peak II, in which mature IGF-II is eluted together with IGF-I, and the peak I, in which high $M_{\mathrm{r}}$ forms of IGF-II are eluted, displayed similar mitogenic activities. As they were both inhibited by the anti-IGF type 1 receptor antibody, we conclude that they do not contain mitogens other than the IGFs active in BP-A31 cells. IGFBP-1 purified from human AF acted as a potent inhibitor of peak II but did not inhibit the activity of peak 
I (note also that IGFBPs co-eluted with the high $M_{\mathrm{r}}$ forms of IGF-II in peak I). From these data, we can assume that the IGFBPs are not efficient inhibitors of the high $M_{\mathrm{r}}$ forms of IGF-II present in the AF. This is probably not due to a lack of binding of high $M_{\mathrm{r}}$ forms of IGF-II to IGFBPs. Valenzano et al. (1997) found no difference in the binding to IGFBP-1 and IGFBP-3 of the foetal bovine high $M_{\mathrm{r}}$ weight forms of IGF-II. Binding characteristics of proIGF-II, extracted from tumours or serum from patients with cancer, to IGFBP-1 to -6 were established: precursor forms of IGF-II did not show any difference from mature IGF-II in their binding to IGFBPs (Bond et al. 2000), except for the formation of a ternary complex with the acid labile subunit (ALS) and IGFBP-3. However, ALS is absent from AF. These results suggest that the precursor forms of IGF-II are particularly efficient activators of the type 1 IGF receptor. In agreement with this interpretation, Valenzano et al. (1997) have shown that the high $M_{\mathrm{r}}$ weight forms of IGF-II bind to the purified IGF type 1 receptor with a higher affinity than mature IGF-II, and that they have a greater biological activity.

Taken together our data indicate that the precursor forms of IGF-II in AF constitute an important pool of biologically active growth factors.

\section{Acknowledgements}

$\mathrm{J}$ B was supported by a grant from INSERM and Z K by a European Union grant (Tempus/PHARE). We thank Dr N Joye for the supply of human AF, L Perrin for the radioimmunoassay of IGFs, M Garbi for help with certain experiments and Professor Y Le Bouc and Professor D Cabrol for helpful discussions.

\section{References}

Avila CG \& Harding R 1991 The development of the gastrointestinal system in fetal sheep in the absence of ingested fluid. Journal of Pediatric Gastroenterology and Nutrition 12 96-104.

Bassett NS, Breier BH, Moore L \& Gluckman PD 1990 Disappearance of labelled IGF-2 from plasma of the ovine fetus in late gestation. Journal of Developmental Physiology 13 295-301.

Baxter RC, Martin JL \& Wood MH 1987 Two immunoreactive binding proteins for insulin-like growth factors in human amniotic fluid: relationship to fetal maturity. Journal of Clinical Endocrinology and Metabolism 65 423-431.

Bessone S, Vidal F, Le Bouc Y, Epelbaum J, Bluet-Pajot MT \& Darmon M 1999 EMK protein kinase-null mice: dwarfism and hypofertility associated with alterations in the somatotrope and prolactin pathways. Developmental Biology 214 87-101.

Binoux M, Lassarre C \& Gourmelen M 1986 Specific assay for insulin-like growth factor (IGF) II using the IGF binding proteins extracted from human cerebrospinal fluid. Journal of Clinical Endocrinology and Metabolism 63 1151-1155.

Blahovec J, Kostecka Z, Mester J \& Cavaille F 1997 Peptide-like substances in sheep amniotic fluid which regulate proliferation of BP-A31 cells. Veterinari Medicina 42 185-189.
Bond JJ, Meka S \& Baxter RC 2000 Binding characteristics of proinsulin-like growth factor-II from cancer patients: binary and ternary complex formation with IGF binding proteins-1 to -6 . Journal of Endocrinology 165 253-260.

Buchou T \& Mester J 1990 Fibroblast growth factor-dependent mitogenic signal transduction pathway in chemically transformed mouse fibroblasts is similar to but distinct from that initiated by phorbol esters. Journal of Cell Physiology 142 559-565.

Buchou T, Charollais RH, Fagot D \& Mester J 1989 Mitogenic activity of phorbol esters and insulin-like growth factor 1 in chemically transformed mouse fibroblasts BP-A31: independent effects and differential sensitivity to inhibition by 3-isobutyl-1-methyl xanthine. Experimental Cell Research 182 129-143

Busby WH Jr, Klapper DG \& Clemmons DR 1988 Purification of a 31000 -dalton insulin-like growth factor binding protein from human amniotic fluid. Isolation of two forms with different biologic actions. Journal of Biological Chemistry 263 14203-14210.

Chard T, Blum WF, Brunjes J, Campbell DJ \& Wathen NC 1994 Levels of insulin-like growth factor-binding protein-2 and insulin-like growth factor-II in maternal serum, amniotic fluid and extraembryonic coelomic fluid at 9-20 weeks of pregnancy. Journal of Endocrinology 142 379-383.

Daughaday WH, Emanuele MA, Brooks MH, Barbato AL, Kapadia M \& Rotwein P 1988 Synthesis and secretion of insulin-like growth factor II by a leiomyosarcoma with associated hypoglycemia. New England Journal of Medicine 319 1434-1440.

DeChiara TM, Efstratiadis A \& Robertson EJ 1990 A growthdeficiency phenotype in heterozygous mice carrying an insulin-like growth factor II gene disrupted by targeting. Nature 345 78-80.

Delhanty PJ \& Han VK 1993 The expression of insulin-like growth factor (IGF)-binding protein-2 and IGF-II genes in the tissues of the developing ovine fetus. Endocrinology 132 41-52.

D'Ercole AJ, Drop SL \& Kortleve DJ 1985 Somatomedin-C/insulin-like growth factor I-binding proteins in human amniotic fluid and in fetal and postnatal blood: evidence of immunological homology. Journal of Clinical Endocrinology and Metabolism 61 612-617.

Duguay SJ, Jin Y, Stein J, Duguay AN, Gardner P \& Steiner DF 1998 Post-translational processing of the insulin-like growth factor-2 precursor. Analysis of $\mathrm{O}$-glycosylation and endoproteolysis. Journal of Biological Chemistry 273 18443-18451.

Ehrhardt RA \& Bell AW 1995 Growth and metabolism of the ovine placenta during mid-gestation. Placenta 16 727-741.

Fagot D, Buquet-Fagot C \& Mester J 1993 Mitogenic signaling by prostaglandins in chemically transformed mouse fibroblasts: comparison with phorbol esters and insulin. Endocrinology 132 1729-1734.

Forhead AJ, Li J, Gilmour RS \& Fowden AL 1998 Control of hepatic insulin-like growth factor II gene expression by thyroid hormones in fetal sheep near term. American Journal of Physiology 275 E149-E156.

Haddad B, Fulla Y, Genest F, Richard B \& Cabrol D 1995 Respiration of amniotic fluid in near-term foetal rabbit. European Journal of Obstetrics and Gynecology and Reproductive Biology 62 247-250.

Haselbacher G \& Humbel R 1982 Evidence for two species of insulin-like growth factor II (IGF II and 'big' IGF II) in human spinal fluid. Endocrinology 110 1822-1824.

Hossenlopp P, Segovia B, Lassarre C, Roghani M, Bredon M \& Binoux M 1990 Evidence of enzymatic degradation of insulin-like growth factor-binding proteins in the $150 \mathrm{~K}$ complex during pregnancy. Journal of Clinical Endocrinology and Metabolism 71 $797-805$.

Hudgins WR, Hampton B, Burgess WH \& Perdue JF 1992 The identification of O-glycosylated precursors of insulin-like growth factor II. Journal of Biological Chemistry 267 8153-8160. 
Itakura A, Kurauchi O, Morikawa S, Furugori K, Mizutani S \& Tomoda Y 1997 Human amniotic fluid motogenic activity for fetal alveolar type II cells by way of hepatocyte growth factor. Obstetrics and Gynecology 89 729-733.

Jansen M, van Schaik FM, van Tol H, Van den Brande JL \& Sussenbach JS 1985 Nucleotide sequences of cDNAs encoding precursors of human insulin-like growth factor II (IGF-II) and an IGF-II variant. FEBS Letters 179 243-246.

Jones JI \& Clemmons DR 1995 Insulin-like growth factors and their binding proteins: biological actions. Endocrine Reviews 16 3-34.

Kelly EJ, Newell SJ, Brownlee KG, Farmery SM, Cullinane C, Reid WA, Jackson P, Gray SF, Primrose JN \& Lagopoulos M 1997 Role of epidermal growth factor and transforming growth factor alpha in the developing stomach. Archives of Diseases in Childhood: Fetal Neonatal Edition 76 F158-F162.

Kimble RM, Breier BH, Gluckman PD \& Harding JE 1999 Enteral IGF-I enhances fetal growth and gastrointestinal development in oesophageal ligated fetal sheep. Journal of Endocrinology 162 227-235.

Kind KL, Owens JA, Robinson JS, Quinn KJ, Grant PA, Walton PE, Gilmour RS \& Owens PC 1995 Effect of restriction of placental growth on expression of IGFs in fetal sheep: relationship to fetal growth, circulating IGFs and binding proteins. Journal of Endocrinology 146 23-34.

Koch CA, Rother KI \& Roth J 1999 Tumor hypoglycemia linked to IGF-II. In Contemporary Endocrinology: The IGF System, ch. 28, pp 675-698. Eds R Rosenfeld \& C Roberts Jr. Towota, NJ: Humana Press Inc.

Kull FC Jr, Jacobs S, Su YF, Svoboda ME, Van Wyk JJ \& Cuatrecasas P 1983 Monoclonal antibodies to receptors for insulin and somatomedin-C. Journal of Biological Chemistry 258 6561-6566.

Laemmli UK 1970 Cleavage of structural proteins during the assembly of the head of bacteriophage T4. Nature 227 680-685.

Lind T, Kendall A \& Hytten FE 1972 The role of the fetus in the formation of amniotic fluid. Journal of Obstetrics and Gynaecology of the British Commonwealth 79 289-298.

Liu F, Baker BK, Powell DR \& Hintz RL 1993 Characterization of proinsulin-like growth factor-II E-region immunoreactivity in serum and other biological fluids. Journal of Clinical Endocrinology and Metabolism 76 1095-1100.

McLellan KC, Hooper SB, Bocking AD, Delhanty PJ, Phillips ID, Hill DJ \& Han VK 1992 Prolonged hypoxia induced by the reduction of maternal uterine blood flow alters insulin-like growth factor-binding protein-1 (IGFBP-1) and IGFBP-2 gene expression in the ovine fetus. Endocrinology 131 1619-1628.

Merimee TJ, Grant M \& Tyson JE 1984 Insulin-like growth factors in amniotic fluid. Journal of Clinical Endocrinology and Metabolism 59 $752-755$.

Mesiano S, Young IR, Hey AW, Browne CA \& Thorburn GD 1989 Hypophysectomy of the fetal lamb leads to a fall in the plasma concentration of insulin-like growth factor I (IGF-I), but not IGF-II. Endocrinology 124 1485-1491.

Nonoshita LD, Wathen NC, Dsupin BA, Chard T \& Giudice LC 1994 Insulin-like growth factors (IGFs), IGF-binding proteins (IGFBPs), and proteolyzed IGFBP-3 in embryonic cavities in early human pregnancy: their potential relevance to maternal-embryonic and fetal interactions. Journal of Clinical Endocrinology and Metabolism 79 1249-1255.

O'Mahoney JV, Brandon MR \& Adams TE 1991 Developmental and tissue-specific regulation of ovine insulin-like growth factor II (IGF-II) mRNA expression. Molecular and Cellular Endocrinology 78 87-96.

Owens JA, Kind KL, Carbone F, Robinson JS \& Owens PC 1994 Circulating insulin-like growth factors-I and -II and substrates in fetal sheep following restriction of placental growth. Journal of Endocrinology 140 5-13.

Rechler MM 1993 Insulin-like growth factor binding proteins. Vitamins and Hormones 47 1-114.

Rohlik QT, Adams D, Kull FC Jr \& Jacobs S 1987 An antibody to the receptor for insulin-like growth factor I inhibits the growth of MCF-7 cells in tissue culture. Biochemical and Biophysical Research Communications 149 276-281.

Shapiro ET, Bell GI, Polonsky KS, Rubenstein AH, Kew MC \& Tager HS 1990 Tumor hypoglycemia: relationship to high molecular weight insulin-like growth factor-II. Journal of Clinical Investigation 85 1672-1679.

Trahair JF \& Harding R 1992 Ultrastructural anomalies in the fetal small intestine indicate that fetal swallowing is important for normal development: an experimental study. Virchows Archiv A-Pathology, Anatomy and Histopathology 420 305-312.

Trahair JF, Harding R, Bocking AD, Silver M \& Robinson PM 1986 The role of ingestion in the development of the small intestine in fetal sheep. Quarterly Journal of Experimental Physiology 71 99-104.

Valenzano KJ, Remmler J \& Lobel P 1995 Soluble insulin-like growth factor II/mannose 6-phosphate receptor carries multiple high molecular weight forms of insulin-like growth factor II in fetal bovine serum. Journal of Biological Chemistry 270 16441-16448.

Valenzano KJ, Heath-Monnig E, Tollefsen SE, Lake M \& Lobel P 1997 Biophysical and biological properties of naturally occurring high molecular weight insulin-like growth factor II variants. Journal of Biological Chemistry 272 4804-4813.

Wang JF, Fraher LJ \& Hill DJ 1990 Characterization of insulin-like growth factor-binding protein in ovine amniotic fluid. Journal of Endocrinology 127 325-333.

Wathes DC, Reynolds TS, Robinson RS \& Stevenson KR 1998 Role of the insulin-like growth factor system in uterine function and placental development in ruminants. Journal of Dairy Science $\mathbf{8 1}$ 1778-1789.

Wintour EM, Laurence BM \& Lingwood BE 1986 Anatomy, physiology and pathology of the amniotic and allantoic compartments in the sheep and cow. Australian Veterinary Journal 63 216-221.

Zapf J, Futo E, Peter M \& Froesch ER 1992 Can ‘big' insulin-like growth factor II in serum of tumor patients account for the development of extrapancreatic tumor hypoglycemia? Journal of Clinical Investigation 90 2574-2584.

Received 12 February 2001

Accepted 22 February 2001 